\title{
Utilizing Mine Tailings as Substitute Construction Material: The Use of Waste Materials in Roller Compacted Concrete
}

\author{
Renato Guiao Gopez \\ Civil Engineering Department, Bulacan State University, Malolos, Philippines \\ Email: zepogrene@yahoo.com
}

Received 21 October 2015; accepted 5 December 2015; published 10 December 2015

Copyright (C) 2015 by author and OALib.

This work is licensed under the Creative Commons Attribution International License (CC BY). http://creativecommons.org/licenses/by/4.0/

\section{(c) (i) Open Access}

\section{Abstract}

Mine tailings (MT) have been used in previous studies as substitute construction material to recycle waste products, especially in hollow blocks and bricks production and as masonry mortar. This study investigated the use of Philex copper-gold mine tailings (PCGMT) in roller compacted concrete (RCC) production, a mining waste material consisting of finely grinded siliceous particles was obtained from Tailings Pond number 2 (TP2) of a Philippine copper and gold mining company. A comprehensive experimental program was conducted to investigate the comparative compressive strength of RCC containing Porac sand (RCCPS) and RCC with copper-gold mine tailings (RCCCGMT), and the durability of RCC with copper-gold mine tailings and fly-ash (RCCCGMTFA). Varying mixtures of RCCPS and RCCCGMT with very low, low, medium, and high cement contents were casted and tested. The compressive strength attained at 28 days by RCCPS and RCCCGMT ranges from 17 to 37 Mega Pascal (MPa) and 17 to $28 \mathrm{Mpa}$, respectively. The obtained values indicate that the latter requires greater amount of cement and the mixtures with compressive strength values greater than $25 \mathrm{Mpa}$ are acceptable for concrete pavement use. The durability of RCCCGMTFA with medium cement content was evaluated by subjecting the specimens to an alternate wetting and drying cycles. After 15 cycles, a remaining strength of $18.7 \mathrm{MPa}$ was obtained which indicated that it could endure stresses due to weather changes in the Philippines. Results show that PCGMT in TP2 are viable sand or fine aggregates substitute in RCC.

\section{Keywords}

Mine Tailings, Roller Compacted Concrete (RCC), Waste Material, Compressive Strength, Durability

Subject Areas: Civil Engineering, Mineral Engineering 


\section{Introduction}

Industrial processes generate significant quantities of disposable or recyclable by-products that pose waste management problems. A tremendous volume of solid by-product comes from mining operations, i.e., mine tailings (MT) are the solid residues left after valuable minerals have been extracted from the ores [1]. Millions of tons of MT are produced by mining companies in the Philippines, such as the Philex Mining Corporation in Padcal, Benguet, and the Marcopper Mining Corporation in Marinduque which had produced about 73,986,478 dry metric tons, and 57,548,403 dry metric tons of MT, respectively, for about ten years [2]. These MT are treated as wastes that require technologies for their disposal through land filling after reaching maximum capacity. And when it reaches its maximum capacity, it will require reclamation.

The stability of stockpiled and landfill mine tailings and tailings impoundment (tailings dam) pose potential hazards to local inhabitants. This was experienced from previous MT related incidents, like the Philex Mining Corporation mine tailings spill in November 2012 due to a breach in Tailings Pond number 3 causing siltation of the nearby water channels, especially Balog Creek which was declared by the environmental investigative mission as "biologically dead" [3], the Marcopper Tapian Pit in March 1996 were 1.5 million tons of MT spilled from storage pit resulting to the evacuation of 1200 residents and siltation of water courses, and the Maricalum MT dam failure in 1982 were about 20 million tons of MT spilled resulting to widespread inundation of agricultural lands up to 1.5 meter high [4]. To prevent such disasters in the future, recycling or reusing MT as construction material is one solution.

Significant amount of sand is consumed annually in construction of concrete structures like concrete foundations and concrete pavements. A viable alternative method of pavement construction is Roller Compacted Concrete (RCC). It is a fast, low cost, high strength, and economical method [5]. It is relatively a stiff, zero-slump concrete mixture that is compacted by vibratory rollers [6]. In this RCC pavement, replacing sand with mine tailings may be possible, or even advantageous. Last 2012, in the study conducted by Ahmari and Zhang [7], copper mine tailings were utilized in producing eco-friendly bricks based on the geopolymerization technology, and the results showed that copper mine tailings could be used to produced eco-friendly mine tailings-based geopolymer bricks since the requirements of American Society for Testing and Materials (ASTM) were satisfied. In USA, at Montana State University-Bozeman, a study on the utilization of MT in making concrete blocks was conducted and the strength was found satisfactory [8]. Mine Tailings from Marcopper Mining Corporation in Marinduque was utilized as fine aggregate in concrete mixture, and the strength was found suitable [9].

This study investigated the use of copper-gold mine tailings from Tailings Pond number 2 of Philex Mining Corporation in Padcal, Benguet as fine aggregates or as substitute to sand in roller compacted concrete (RCC) production. Generally, the study aims to further assess the suitability of mine tailings as fine aggregates in concrete mixture, to minimize the accumulation of mining solid wastes, and to contribute to national development by converting this waste into useful construction materials. Specifically, this study seeks to answer the following sub-problems: 1) Is there a significant effect of cement content on the compressive strengths of roller compacted concrete with Porac sand (RCCPS) and roller compacted concrete with Philex copper-gold mine tailings (RCCCGMT)?; 2) Is there a significant relation between the compressive strength and cement content of RCCPS and RCCCGMT?, and 3) When subjected to accelerated weathering test (48 hours of alternate wetting and drying cycles), how durable is RCC with Philex copper-gold mine tailings and fly-ash (RCCCGMTFA)?

\section{Methodology}

Method of graph trend comparison and statistical analysis were used to investigate the compressive strengths of RCCPS and RCCCGMT, and durability of RCCCGMTFA. Regression analysis using Minitab 16 software was used in order to verify the validity of the results. Laboratory experiments performed like methods of proportioning, mixing, casting, curing, and testing of RCC specimens were based on standards set by American Concrete Institute (ACI) Manual of Concrete Practice, and American Society for testing and Materials (ASTM) standards. Using RCCPS as the norm, its regression graph trend was compared to that of RCCCGMT regression graph trend. In addition, the results of Sorsogon and Pinatubo aggregates regression graphs trend studied by Mendoza [10] were also utilized for comparison. Similarly, the durability of RCCCGMTFA was evaluated by comparing its regression graph trend to those of Sorsogon and Pinatubo regression graph trends.

The experimental program of this study consists of the following: (a) sieve analysis of aggregates; (b) materials physical and chemical properties characterization; and (c) evaluation of concrete mixes as outlined in the three series of Table 1, the Summarized Experiment Program. In all the series, the maximum size of aggregate 
Table 1. Summarized experiment program.

\begin{tabular}{|c|c|c|c|c|c|}
\hline Mix Code & Variables & Range & Batch & Controlled Variables & Test \\
\hline \multicolumn{6}{|c|}{ - Series 1: Compressive Strength of RCC with Porac Sand (RCCPS) } \\
\hline $\begin{array}{l}\cdot S 1 / 200 \\
\cdot S 1 / 300 \\
\cdot S 1 / 400 \\
\cdot S 1 / 500\end{array}$ & $\begin{array}{l}\text { •Cement } \\
\text { content }\end{array}$ & $\begin{array}{l}\cdot 200 \mathrm{~kg} / \mathrm{m}^{3} \\
\cdot 300 \mathrm{~kg} / \mathrm{m}^{3} \\
\cdot 400 \mathrm{~kg} / \mathrm{m}^{3} \\
\cdot-500 \mathrm{~kg} / \mathrm{m}^{3}\end{array}$ & 4 & $\begin{array}{l}\text { - Maximum Size of Aggregate = } 19 \mathrm{~mm} \\
\text { - Air content = } 2 \% \text { to } 3.5 \% \\
\text { - Slump = Zero } \\
\text { - Consistency }=70 \% \text { to } 75 \%\end{array}$ & •Compression \\
\hline \multicolumn{6}{|c|}{ - Series 2: Compressive Strength of RCC with Philex Copper-Gold Mine Tailings as Fine Aggregate (RCCCGMT) } \\
\hline $\begin{array}{l}\cdot \mathrm{S} 2 / 200 \\
\cdot \mathrm{S} 2 / 300 \\
\cdot \mathrm{S} 2 / 400 \\
\cdot \mathrm{S} 2 / 500\end{array}$ & $\begin{array}{l}\text { •Cement } \\
\text { content }\end{array}$ & $\begin{array}{l}\cdot 200 \mathrm{~kg} / \mathrm{m}^{3} \\
\cdot 300 \mathrm{~kg} / \mathrm{m}^{3} \\
\cdot 400 \mathrm{~kg} / \mathrm{m}^{3} \\
\cdot 500 \mathrm{~kg} / \mathrm{m}^{3}\end{array}$ & 4 & $\begin{array}{l}\text { - Maximum Size of Aggregate = } 19 \mathrm{~mm} \\
\text { - Air content }=2 \% \text { to } 3.5 \% \\
\text { - Slump }=\text { Zero } \\
\text { - } \text { Consistency }=70 \% \text { to } 75 \%\end{array}$ & •Compression \\
\hline \multicolumn{6}{|c|}{ - Series 3: Durability of RCC with Philex Copper-Gold Mine Tailings and 20\% Fly-Ash (RCCCGMTFA) } \\
\hline $\begin{array}{l}\cdot \mathrm{S} 3 / 400 / 20 \\
\cdot \mathrm{S} 3 / 400 / 20 \\
\cdot \mathrm{S} 3 / 400 / 20 \\
\cdot \mathrm{S} 3 / 400 / 20 \\
\cdot \mathrm{S} 3 / 400 / 20\end{array}$ & $\begin{array}{l}\text { • Number } \\
\text { of Cycle }\end{array}$ & $\begin{array}{l}\cdot 7^{\text {th }} \text { day, } \\
\cdot 3^{\text {rd }} \text { cycle, } \\
\cdot 6^{\text {th }} \text { cycle, } \\
\cdot 9^{\text {th }} \text { cycle, } \\
\cdot 15^{\text {th }} \text { cycle }\end{array}$ & 1 & $\begin{array}{l}\text { - Cement }=400 \mathrm{~kg} / \mathrm{m}^{3} \\
\text { - } \text { Fly ash = } 20 \% \text { (class "F") } \\
\text { - } \text { Maximum Size of Aggregate = } 19 \mathrm{~mm} \\
\text { - Air content = } 2 \% \text { to } 3.5 \% \\
\text { - Slump = Zero } \\
\text { - } \text { Consistency }=70 \% \text { to } 75 \%\end{array}$ & •Compression \\
\hline
\end{tabular}

(MSA), the air content, the slump, the consistency, and the type of cement were treated as controlled variables; and the method of mixing, compaction, casting, and curing were held constant. The RCC specimens were cured and tested at 7,28 , and 63 days.

Series 1 and 2 are the series for the evaluation of the effect of cement content to the compressive strengths of RCCPS and RCCCGMT. Varying quantity of cement such as $200 \mathrm{~kg} / \mathrm{m}^{3}, 300 \mathrm{~kg} / \mathrm{m}^{3}, 400 \mathrm{~kg} / \mathrm{m}^{3}$, and $500 \mathrm{~kg} / \mathrm{m}^{3}$ were used to cast RCCPS and RCCCGMT specimens. Fresh properties such as slump, consistency, air content, and yield were measured in every batch.

Series 3 in Table 1 is the evaluation of the durability of RCCCGMTFA. In this series, class "F" fly ash, another controlled variable was used due to its advantages when added in concrete mixture such as improving mixture workability, good influence on the rate of strength development, and durability to thermal cracking [11] [12]. Fifteen (15) standard cylinder specimens were casted from the optimum values of the mix proportions and were subjected to accelerated weathering for durability test. Consequently, three specimens were tested to compressive strength at seven days, and the rest were subjected to alternate oven drying at approximately $100^{\circ} \mathrm{C} \pm$ $5^{\circ} \mathrm{C}$ for 48 hours and wetting by soaking in water for another 48 hours within 15 cycles. Compression test was conducted every third cycle of alternate wetting and drying.

\section{Results and Discussion}

\subsection{Comparison of the Sieve Analysis and Physical Properties Results of PCGMT and Porac Sand to the Normal Ranges for Fine Aggregates of RCC}

Table 2 presents the sieve analysis results of Porac sand and PCGMT, and the grading requirements of ASTM C 33 for fine aggregates. It could be noted that the percentage passing values of PCGMT at the smaller sieve openings from $0.15 \mathrm{~mm}$ to $1.19 \mathrm{~mm}$ are greater than the ASTM C 33 upper limit requirement. For the Porac sand, all of the percentage passing values are within the ASTM C 33 lower and upper limit requirements. Like in the finest sieve opening of $0.15 \mathrm{~mm}$, the value of percentage passing for PCGMT is $18.97 \%$ which is $8.97 \%$ higher than the ASTM C 33 upper limit requirement of $10 \%$, while for Porac sand has a value of $4.72 \%$ which is above the lower limit value of $2 \%$ and below the upper limit value of $10 \%$. In the sieve opening of $0.59 \mathrm{~mm}$, PCGMT percentage passing is $20.47 \%$ higher than the upper limit value. These values indicate that PCGMT is finer than the standard fine aggregates used for concrete, however, ASTM C 33 section 6.4 stated that "fine aggregate failing to meet the sieve analysis and fineness modulus requirements may be accepted provided that concrete made with similar fine aggregate from the same source has an acceptable performance record in similar concrete construction; or in the absence of a demonstrable service record, provided that it is demonstrated that concrete of the class specified, made with the fine aggregate under consideration, will have relevant properties at least or equal to those of concrete made with the same ingredients”. 
Table 2. Sieve analysis of fine aggregates as compared to ASTM C 33 grading requirements.

\begin{tabular}{|c|c|c|c|c|c|}
\hline \multirow{2}{*}{$\begin{array}{l}\text { Sieve Opening, } \\
\text { (mm) }\end{array}$} & \multirow{2}{*}{$\begin{array}{l}\text { Weight of Sieve, } \\
\quad \text { (grams) }\end{array}$} & \multirow{2}{*}{$\begin{array}{c}\text { Porac } \\
\text { Sand } \\
\text { (\% Passing) }\end{array}$} & \multirow{2}{*}{$\begin{array}{l}\text { Mine Tailings } \\
\text { (PCGMT) } \\
\text { (\% Passing) }\end{array}$} & \multicolumn{2}{|c|}{ ASTM Specification E11, (\%Passing) } \\
\hline & & & & Lower Limit & Upper Limit \\
\hline 9.52 & 512.50 & 100.00 & 100.00 & 100 & 100 \\
\hline 4.76 & 458.90 & 100.00 & 100.00 & 95 & 100 \\
\hline 2.50 & 427.60 & 97.56 & 98.47 & 80 & 100 \\
\hline 1.19 & 438.70 & 82.22 & 94.57 & 50 & 85 \\
\hline 0.59 & 388.40 & 50.88 & 80.47 & 25 & 60 \\
\hline 0.30 & 374.40 & 22.46 & 48.54 & 10 & 30 \\
\hline 0.15 & 351.80 & 4.72 & 18.97 & 2 & 10 \\
\hline Pan & 348.10 & 0.00 & 0.00 & 0 & 0 \\
\hline
\end{tabular}

Figure 1 which is the graphical presentation of Table 2, present the trend of sieve analysis result regression graphs for Porac sand, PCGMT, and for the lower limit and upper limit specifications of ASTM C 33. Porac sand grading curve depicts conformity with ASTM standards since it falls within the upper and lower limit ASTM grading curves, while PCGMT grading curve is higher than the upper limit curve indicating that the particles are finer than standard fine aggregate. This indicates that for PCGMT an increase in water requirement and cement contents for a constant water/cement ratio concrete mixture will be expected [11] [13].

Table 3 shows the laboratory experiment results of physical properties of gravel, sand, mine tailings, cement, and fly-ash used in this study. These are necessary in the calculation of the mix proportions and correction of batch water for RCC. It presents the physical properties of PCGMT that reflect its potentials as fine aggregate, like (a) its apparent specific gravity is 2.64 , slightly greater than normal range of $2.20-2.60$, owing that to its magnetite content, a mineral used for making heavy weight aggregates; (b) its dry-rodded density is 1656.59 $\mathrm{kg} / \mathrm{m}^{3}$, is within the range of $1300-1750 \mathrm{~kg} / \mathrm{m}^{3}$ [11]; (c) its absorption is $1.54 \%$ which is satisfactory because it is within the typical range of $0.20 \%-4.53 \%$; and (d) its fineness modulus is 1.6 , lower than the range of 2.3 3.1 common for fine aggregates [14].

\subsection{Comparison of the Sieve Analysis and Physical Properties Results of PCGMT and Porac Sand to the Normal Ranges for Fine Aggregates of RCC}

Table 4 shows the results of the chemical analysis of PCGMT. The chemical composition of PCGMT revealed that the iron content is $6.140 \%$ which classifies it as a corrosive material. If this material will be used on RCC with steel reinforcement bars, formation of cracks on the concrete should be minimized by using class "F" flyash [11] [12] so that oxidation process will not occur. This will prevent or minimized the intrusion of water and air that causes the formation of rust or dehydrated iron (III) hydroxide $\left(\mathrm{Fe}_{2} \mathrm{O}_{3}\right)$.

\subsection{Effect of Cement Content to the Compressive Strength of RCCPS and RCCCGMT}

Series 1 and 2 of Table 5 presents the calculated RCC constituents mix proportions and compressive strength test results of RCCPS and RCCCGMT specimens.

The mix proportion results in Series 1 and 2 of Table 5 shows that for each mix code of each series, the water requirement of MT is always greater than Porac sand, this is due to the fineness of MT particles than Porac sand. As Gambhir stated, finer aggregate requires more water, and Neville said, the larger the aggregate particle the smaller the surface area to be wetted per unit weight [11] [14]. It can be noted also that as the water and cement content increases, the Porac sand and MT content decreases. This change in mass of the constituents is due to the requirement that the totality of the proportions should always be approximately equal to one cubic meter. Likewise, an increase or decrease on the amount of the materials is dictated by the workability and strength requirements of the mixture. It could be noted that the amount of coarse aggregate is constant in the four batches of mixtures of series 1 and 2 . That is because of ACI requirement that, the coarse aggregate amount is dependent 


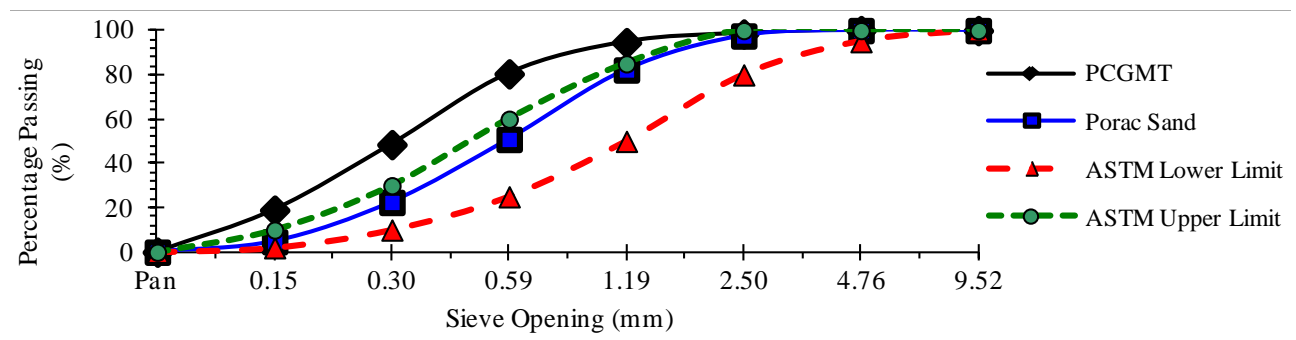

Figure 1. Grading curves for Porac sand, PCGMT, and ASTM C33 upper \& lower limit specifications.

Table 3. Physical properties of materials.

\begin{tabular}{cccccc}
\hline & \multicolumn{3}{c}{ Materials } \\
\cline { 2 - 6 } Properties & $\begin{array}{c}\text { Crushed Gravel, } \\
\text { Montalban, } \\
\text { MSA }=19 \mathrm{~mm}\end{array}$ & Porac Sand & $\begin{array}{c}\text { Mine Tailings } \\
\text { (PCGMT) }\end{array}$ & $\begin{array}{c}\text { Portland } \\
\text { Cement, } \\
\text { Type I }\end{array}$ & $\begin{array}{c}\text { Fly-Ash } \\
\text { Class "F" }\end{array}$ \\
\hline Apparent Specific Gravity & 2.87 & 2.31 .00 & 2.64 & 3.12 & 2.80 \\
Dry-rodded Unit Weight, kg/m & 1624.81 & 1568.47 & 1656.59 & - & - \\
Absorption, \% & 1.13 & 4.50 & 1.54 & - & - \\
Moisture Content, \% & 2.04 & 3.61 & 3.93 & - & - \\
Fineness Modulus (FM) & 6.70 & 2.40 & 1.60 & - & - \\
\hline
\end{tabular}

Table 4. Chemical analysis result of PCGMTa.

\begin{tabular}{ccccccc}
\hline Elements & Iron (\%) & Calcium Oxide (\%) & Insolubles (\%) & Zinc (ppm) & Arsenic (ppm) & Cadmium (ppm) \\
\hline Results & 6.140 & 0.460 & 77.700 & 41.700 & Nil & 2.000 \\
\hline Elements & Copper (\%) & Calcium (\%) & Magnesium (\%) & Manganese (ppm) & Cobalt (ppm) & Bismuth (ppm) \\
\hline Results & 0.087 & 0.330 & 0.298 & 421.000 & 15.700 & 22.500 \\
\hline Elements & Sulfur (\%) & Magnesium Oxide (\%) & Lead (ppm) & Chromium (ppm) & Mercury(ppm) & Antimony (ppm) \\
\hline Results & 1.080 & 0.497 & 15.700 & 16.500 & 0.111 & Nil \\
\hline
\end{tabular}

a. Chemical analysis was conducted and provided by Philex Mining Corporation.

Table 5. RCC constituents mix proportions and compressive strength test results for series 1 and 2.

\begin{tabular}{|c|c|c|c|c|c|c|c|c|}
\hline \multicolumn{9}{|c|}{ - Series 1: RCC with Porac Sand as Fine Aggregate (RCCPS) } \\
\hline \multirow{2}{*}{$\begin{array}{c}\text { Mix } \\
\text { Code }\end{array}$} & \multirow{2}{*}{$\begin{array}{c}\text { Water } \\
(\mathrm{kg})\end{array}$} & \multirow{2}{*}{$\begin{array}{l}\text { Cement } \\
\text { Type I } \\
\text { (kg) }\end{array}$} & \multirow{2}{*}{$\begin{array}{l}\text { Porac } \\
\text { Sand } \\
\text { (kg) }\end{array}$} & \multirow{2}{*}{$\begin{array}{l}\text { Mine Tailings } \\
\text { (PCGMT) } \\
\text { (kg) }\end{array}$} & \multirow{2}{*}{$\begin{array}{c}\text { Gravel } \\
(20-25 \mathrm{~mm}) \\
(\mathrm{kg})\end{array}$} & \multicolumn{3}{|c|}{ Average Compressive Strength (MPa) } \\
\hline & & & & & & 7 days & 28 days & 63 days \\
\hline S1/200 & 83 & 200 & 966 & - & 1190 & 6.40 & 7.40 & 10.70 \\
\hline $\mathrm{S} 1 / 300$ & 100 & 300 & 854 & - & 1190 & 16.30 & 16.90 & 20.70 \\
\hline $\mathrm{S} 1 / 400$ & 116 & 400 & 741 & - & 1190 & 30.10 & 33.20 & 38.40 \\
\hline $\mathrm{S} 1 / 500$ & 130 & 500 & 633 & - & 1190 & 35.20 & 37.40 & 44.90 \\
\hline \multicolumn{9}{|c|}{ • Series 2: RCC with Philex Copper-Gold Mine Tailings as Fine Aggregate (RCCCGMT) } \\
\hline \multirow{2}{*}{$\begin{array}{c}\text { Mix } \\
\text { Code }\end{array}$} & \multirow{2}{*}{$\begin{array}{c}\text { Water } \\
(\mathrm{kg})\end{array}$} & \multirow{2}{*}{$\begin{array}{l}\text { Cement } \\
\text { Type I } \\
\text { (kg) }\end{array}$} & \multirow{2}{*}{$\begin{array}{l}\text { Porac } \\
\text { Sand } \\
(\mathrm{kg})\end{array}$} & \multirow{2}{*}{$\begin{array}{l}\text { Mine Tailings } \\
\text { (PCGMT) } \\
\text { (kg) }\end{array}$} & \multirow{2}{*}{$\begin{array}{c}\text { Gravel } \\
(20-25 \mathrm{~mm}) \\
(\mathrm{kg})\end{array}$} & \multicolumn{3}{|c|}{ Average Compressive Strength (MPa) } \\
\hline & & & & & & 7 days & 28 days & 63 days \\
\hline S2/200 & 112 & 200 & - & 1003 & 1227 & 8.30 & 9.70 & 10.30 \\
\hline S2/300 & 118 & 300 & - & 919 & 1227 & 15.30 & 17.80 & 20.00 \\
\hline $\mathrm{S} 2 / 400$ & 125 & 400 & - & 842 & 1227 & 21.70 & 25.50 & 28.50 \\
\hline S2/500 & 132 & 500 & - & 742 & 1227 & 24.80 & 28.50 & 32.70 \\
\hline
\end{tabular}


to the fineness modulus (FM) of sand, maximum size aggregate (MSA), mix consistency, and its dry-rodded unit weight. In Series 2, the Porac sand amount in Series 1 was replaced by PCGMT, and it could be seen that the amount of coarse aggregate had increased in this series due to the lower value of FM of mine tailings than sand, indicating that the average particle size of mine tailings is smaller than that of sand. Likewise, from this reason the amount of water requirements had increased as reflected in the table, which is the general trend for aggregates, that is, finer aggregates require greater water content than coarser one.

The compressive strength test results in Table 5 show that in both series, as the cement content increases the compressive strength also increases. This means the cement content is directly proportional to the compressive strength of RCCPS, and RCCCGMT specimens. These values follow the normal behavior and common relationship between cement content and compressive strength of concrete. From the data, it could be noted that generally RCCPS has greater compressive strength than RCCCGMT and that is due to the lower water/cement ratio of RCCPS than RCCCGMT. The same behavior and trend of compressive strength test results was obtained in the study for concrete with Sorsogon and Pinatubo aggregates conducted by Mendoza [10]. Generally at some extent in any concrete mixture, as the water/cement ratio decreases the compressive strength increases. This was found by Duff Abrams in 1918 at the Lewis Institute, University of Illinois, and was popularly known as Abram's water/cement ratio rule [11] [14].

In Figure 2, the trend of the regression graphs for the effect of cement content to the compressive strength of RCCPS and RCCCGMT follow the same behavior similar to concrete with Sorsogon and Pinatubo aggregates [10] and to normal concrete mixture [11] [14]. The trend of the regression lines also reflects that RCCCGMT needs greater amount of cement than RCCPS to attain more strength. This is because Philex CGMT is finer than Porac sand, which requires greater amount of cement to gain higher strength. And from the data shown, the optimum amount of cement which gives a reasonable strength after 28 days and more likely to be economical is $400 \mathrm{~kg} / \mathrm{m}^{3}$. It has a compressive strength of $21.7 \mathrm{MPa}$ after 7 days, and $25.5 \mathrm{MPa}$ after 28 days of curing which is above the allowable compressive strength of $25 \mathrm{MPa}$ in the design of road pavements [15].

\subsection{Durability of RCCCGMTFA When Subjected to Accelerated Weathering Test}

Table 6 and Figure 3 present the results of the durability (accelerated weathering) test conducted on RCCCGMTFA. It could be seen that the specimens have compressive strengths of $20.1 \mathrm{MPa}$ after 3rd cycle, 20.9 MPa after the 6th cycle, 19.5 MPa after the 9th cycle, and 18.7 MPa after the 15th cycle, wherein one cycle is approximately equivalent to 28 days of conventional curing [10]. The trend depicted in Figure 3 indicates that RCC develops compressive strength at a certain span of time and deteriorates afterwards due to the formations of micro cracks between the aggregates and cement paste caused by swelling and shrinking of concrete [11].
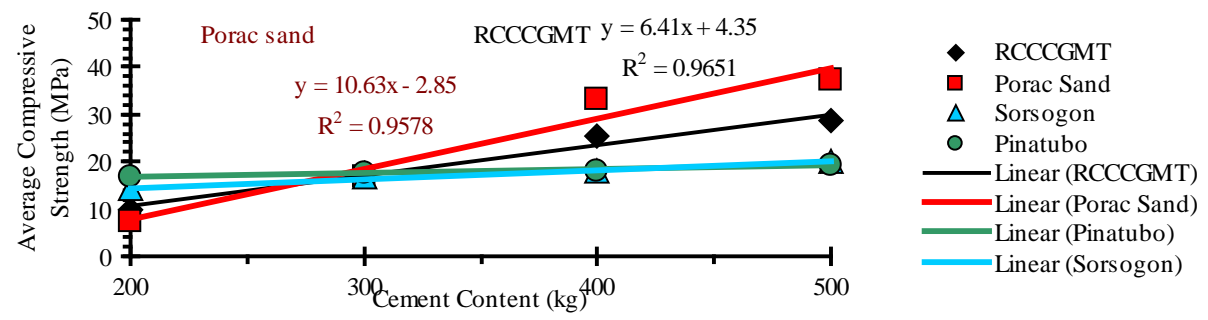

Figure 2. Effect of cement content to compressive strength of RCCPS and RCCCGMT at 28 days as compared to sorsogon and pinatubo aggregates.

Table 6. RCCCGMTFA constituents mix proportions and compressive strength test results of series three.

\begin{tabular}{|c|c|c|c|c|c|c|c|c|c|c|}
\hline \multicolumn{11}{|c|}{ Series 3: Durability of RCC with Philex Copper-Gold Mine Tailings and 20\% Fly-Ash (RCCCGMTFA) } \\
\hline \multirow[b]{2}{*}{ Mix Code } & \multirow[b]{2}{*}{$\begin{array}{c}\text { Water } \\
\text { (kg) }\end{array}$} & \multirow{2}{*}{$\begin{array}{c}\text { Cement } \\
\text { Type I } \\
\text { (kg) }\end{array}$} & \multirow{2}{*}{$\begin{array}{l}\text { Fly Ash } \\
\text { Class "F" } \\
\text { (kg) }\end{array}$} & \multirow{2}{*}{$\begin{array}{c}\text { Mine Tailings } \\
\text { (PCGMT) } \\
\text { (kg) }\end{array}$} & \multirow{2}{*}{$\begin{array}{c}\text { Gravel } \\
(20-25 \mathrm{~mm}) \\
(\mathrm{kg})\end{array}$} & \multicolumn{5}{|c|}{ Average Compressive Strength, MPa } \\
\hline & & & & & & 7days & $\begin{array}{c}3^{\text {rd }} \\
\text { Cycle }\end{array}$ & $\begin{array}{c}6^{\text {th }} \\
\text { Cycle }\end{array}$ & $\begin{array}{c}9^{\text {th }} \\
\text { Cycle }\end{array}$ & $\begin{array}{l}15^{\text {th }} \\
\text { Cycle }\end{array}$ \\
\hline $\mathrm{S} 3 / 400 / 20$ & 136 & 320 & 80 & 751 & 1227 & 18.90 & 20.10 & 20.90 & 19.50 & 18.70 \\
\hline
\end{tabular}




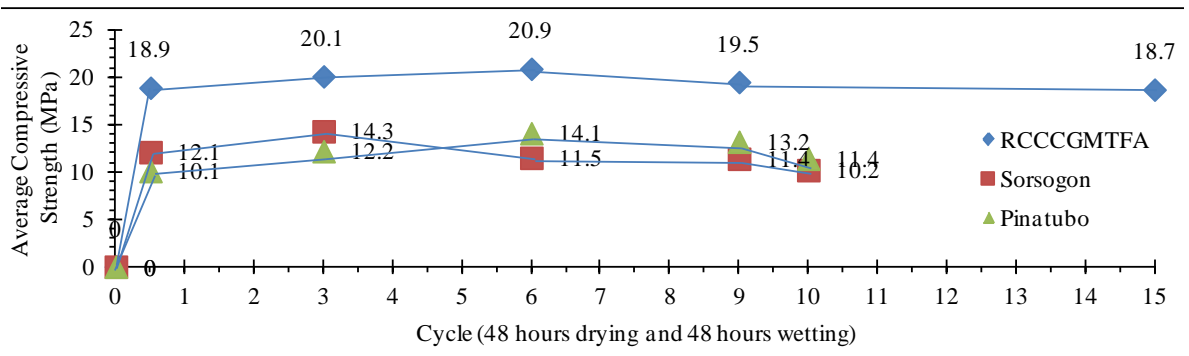

Figure 3. Compressive strength development of RCCCGMTFA after subjecting to alternate drying and wetting (accelerated weathering test).

From the graphs in Figure 3, RCCCGMTFA reflects the same behavior as that of concrete with Pinatubo sand and with Sorsogon sand [10], indicating that it could endure stresses due to weather changes in the Philippines.

\subsection{Statistical Analysis}

Aside from statistical graph trend comparison (shown in Figure 2 and Figure 3), statistical techniques like Pearson Product Moment Coefficient or Linear Correlation Coefficient, Linear Regression Analysis, and F-test (ANOVA) using Microsoft Office Excel, Microsoft Office Word Chart, and Minitab 16 Software (shown in Table 7 and Table 8) were also used to determine the following: (a) Correlation between compressive strength and cement content of RCCPS and RCCCGMT, and (b) Linear relations between compressive strength and cement content of RCCPS and of RCCCGMT, and significance of the independent variable coefficient $\boldsymbol{\beta}_{\mathbf{1}}$ (slope) in the linear regression equation, $\ddot{\mathbf{Y}}=\boldsymbol{\beta}_{\mathbf{O}}+\boldsymbol{\beta}_{\mathbf{1}} \mathbf{X}$.

\subsubsection{Correlations between Compressive Strength and Cement Content}

Table 6 shows the results of correlation analysis between compressive strength and cement content of RCCPS and RCCCGMT.

Null Hypothesis: There is no correlation between the compressive strength and cement content of RCCPS and RCCCGMT. Ho:r $=0$

Alternative Hypothesis: There is a correlation between the compressive strength and cement content of RCCPS and RCCCGMT. Ha:r it not equal to 0

As seen from the results of hypothesis test of the significance of Pearson Correlation Coefficient $r$, the values obtained show that there is a linear correlation between the compressive strength and cement content of RCCPS and RCCCGMT since the computed r-value and t-test value are greater than the r-critical and t-critical values, respectively. This resulted to the rejection of the Null hypothesis. In addition, P-value of 0.001 is lesser than the significance level of 0.025 indicating that there is significant linear correlation between the two samples.

\subsubsection{Linear Relations between Compressive Strength and Cement Content}

Table 8 presents the statistical results generated by using Minitab 16 software, where linear relations between compressive strength and cement content of RCCPS and of RCCCGMT, and significance of the independent variable coefficient $\boldsymbol{\beta}_{\mathbf{1}}$ (slope) in the linear regression equation, $\ddot{\mathbf{Y}}=\boldsymbol{\beta}_{\mathbf{O}}+\boldsymbol{\beta}_{\mathbf{1}} \mathbf{X}$, for both RCCPS and RCCCGMT were tested and analyzed, where $\ddot{\mathbf{Y}}=$ Compressive strength.

Dependent variable (Response variable): Compressive strength of RCCPS and RCCCGMT;

Independent variable: X: Cement content of RCCPS and RCCCGMT.

Null Hypothesis: There is no significant linear relation between the compressive strength and cement content of RCCPS and RCCCGMT. Ho: $\mu_{1}$ is not equal to $\mu_{2}$ and $\beta_{1}=0$.

Alternative Hypothesis: There is a significant linear relation between the compressive strength and cement content of RCCPS and RCCCGMT. Ha: $\mu_{1}=\mu_{2}$ and $\beta_{1}$ is not equal to 0 .

General regression analysis outputs revealed that compressive strength is linearly related to cement content of RCCPS and RCCCGMT. The F-values (45.411 and 55.323) are greater than F-critical values (0.938 and 0.986$)$ resulting to the rejection of the Null Hypothesis. The P-values of 0.021 and 0.018 are both below the level of significance value of 0.05 which indicates that there is significant evidence of linear relationships of the two variables. The $\mathrm{R}^{2}$ values show that the models explain $95.78 \%$ and $96.51 \%$ of the variance in compressive strengths, 
Table 7. Measure of degree of association of the linear relationship between two samples using linear correlation coefficient or pearson product moment correlation coefficient, $r$.

\begin{tabular}{|c|c|c|c|c|c|c|}
\hline \multirow{3}{*}{ Comparison } & \multirow{3}{*}{ Significance Level } & \multicolumn{5}{|c|}{ Hypothesis Test of the Significance of $r$} \\
\hline & & \multicolumn{2}{|c|}{$\begin{array}{l}\text { Test Statistic } \mathrm{r} \text { for } \\
\text { Linear Correlation }\end{array}$} & \multicolumn{2}{|c|}{$\begin{array}{l}\text { Test Statistic t for } \\
\text { Linear Correlation }\end{array}$} & \multirow{2}{*}{$P$-value } \\
\hline & & r-value & r-critical & t-test value & t-critical & \\
\hline $\begin{array}{l}\text { Compressive Strength vs. Cement } \\
\text { Content of RCCPS and RCCCGMT }\end{array}$ & 0.05 (two-tailed) & 0.938 & 0.707 & 6.624 & 2.447 & 0.001 \\
\hline
\end{tabular}

Table 8. Linear relationship of two samples by general regression analysis using Minitab 16 software.

\begin{tabular}{|c|c|c|c|c|c|c|c|c|c|}
\hline \multirow{2}{*}{ Comparison } & \multicolumn{3}{|c|}{ ANOVA } & \multirow{2}{*}{$\mathrm{R}^{2}$} & \multicolumn{4}{|c|}{ Test of the Significance of Coefficient $\beta_{1}$} & \multirow[b]{2}{*}{$\mathrm{SE}^{\mathrm{a}} \aleph^{\prime}$} \\
\hline & F-value & F-critical & P-value & & Coefficient $\beta_{1}$ & T-value & t-critical & $P$-value & \\
\hline \multirow{2}{*}{$\begin{array}{c}\text { RCCPS } \\
\text { Compressive Strength } \\
\text { vs. Cement Content }\end{array}$} & 45.411 & 0.938 & 0.021 & \multirow[b]{2}{*}{$95.78 \%$} & 0.1063 & 6.739 & 9.925 & 0.021 & 0.0158 \\
\hline & \multicolumn{3}{|c|}{$\begin{array}{l}\text { Regression Equation: } \\
\ddot{\mathbf{Y}}=-\boldsymbol{\beta} \mathbf{0}+\boldsymbol{\beta}_{\mathbf{1}} \mathbf{X}\end{array}$} & & \multicolumn{4}{|c|}{$\begin{array}{c}\text { Regression Equation: } \\
\text { RCCPS }=-13.48+0.1063 \text { Cement }\end{array}$} & \\
\hline \multirow{2}{*}{$\begin{array}{c}\text { RCCCGMT } \\
\text { Compressive Strength } \\
\text { vs. Cement Content }\end{array}$} & 55.323 & 0.986 & 0.018 & \multirow[b]{2}{*}{$96.51 \%$} & 0.0641 & 7.438 & 9.925 & 0.018 & 0.0086 \\
\hline & \multicolumn{3}{|c|}{$\begin{array}{l}\text { Regression Equation: } \\
\ddot{\mathbf{Y}}=-\boldsymbol{\beta} \mathbf{0}+\boldsymbol{\beta}_{\mathbf{1}} \mathbf{X}\end{array}$} & & RCCCGI & $\begin{array}{l}\text { gression } \mathrm{E} \\
\Gamma=-2.06\end{array}$ & $\begin{array}{l}\text { uation: } \\
0.0641 \mathrm{Ce}\end{array}$ & & \\
\hline
\end{tabular}

a. Standard Error of Estimate (SE), ß’.

indicating that the models fit the data well. Furthermore, using the Standard Error of Estimate $\beta^{\prime}$ ' values $(0.0158$ and 0.0086$)$ and the independent variable coefficient $\boldsymbol{\beta}_{1}$ values $(0.1063$ and 0.0641$)$, the computed T-values (6.739 and 7.438) are greater than t-critical values $(0.021$ and 0.018$)$ which indicate that the independent variable $\mathrm{X}$ could be used to predict the value of the dependent variable $\ddot{\mathbf{Y}}$ using the linear equation $\ddot{\mathbf{Y}}=\boldsymbol{\beta}_{\mathbf{O}}+\boldsymbol{\beta}_{1} \mathbf{X}$. Thus, the two variables are linearly related.

\section{Conclusions and Recommendations}

The acceptability of utilizing mine tailings from Philex Mining Corporation as substitute to sand on roller compacted concrete production was found satisfactory on the basis of sieve analysis and physical properties outputs, compressive strengths, and durability as depicted by the plotted graph behavior of the data from the results of experiments conducted in this study. Based on the graph trend comparison, the graph behavior for RCCCGMT (the sample under study) is similar to the graph behavior of RCCPS (the sample for basis of the study), indicating that the Philex copper-gold mine tailings obtained in TP\#2 is suitable to be used as fine aggregate and as substitute for sand in RCC production on the basis of compressive strength and durability properties.

Results from statistical analysis such as Correlation, Regression, T-test, and ANOVA between the compressive strengths and cement content of RCCPS and RCCCGMT suggest that the variables ( $\ddot{\mathbf{Y}}$ and $\mathbf{X}$ ) are correlated and linearly related, meaning that cement content has significant effects on the compressive strengths of both RCCPS and RCCCGMT.

On the basis of the significant findings and conclusions of this study, the following are posited as recommendations: a) Parallel and further studies be conducted using mine tailings from Tailings Pond Number 1 (TP\#1) and 3 (TP\#3) of Philex Mining Corporation, b) We can conduct a study on the effects of using and blending mine tailings with mineral admixtures and super plasticizers, c) We can further validate the strength of concrete with mine tailings, and d) Due to its iron content, it is further recommended that in the future studies, corrosion resistance test should also be conducted if the subject tailings will be used for reinforced RCC.

\section{Acknowledgements}

The author would like to thank the following: Philex Mining Corporation, Department of Environment and Natural Resources, and Bureau of Mines and Geosciences. 


\section{References}

[1] Environment Law Alliance Worldwide (2010) Guidebook for Evaluating Mining Project EIAs, Chapter 1. 5-6. http://www.elaw.org/files/mining-eia-guidebook/Chapter1.pdf

[2] (2001) Summary of Ten-Year Production of Mine Tailings from Selected Large-Scale Mining Corporations in the Philippines. Unpublished Report, Department of Environment and Natural Resources (DENR), Mines and Geosciences Bureau (MGB), Mine Environmental Section. https://www.mgb.gov.ph

[3] Dinglasan, R. R. (2012) GMA News. http://www.gmanetwork.com/news/story/281988/news/nation/philex-spill-biggest-mining-disaster-in-phl-surpassing-m arcopper-denr\#sthash.CUOu1cyV.dpuf

[4] Chronology of Tailings Dam Failures in the Philippines (1982-2007). http://www.piplinks.org/system/files/Tailings+dam+failures+(070722).doc

[5] Nanni, A., Ludwig, D. and Shoenberger, J. (1996) Roller Compacted Concrete for Highway Pavements. Concrete International, 18, 33-38.

[6] ACI 207.5R-11 (2011) Roller Compacted Concrete. American Concrete Institute (ACI), Farminton Hills.

[7] Ahmari, S. and Zhang, L.Y. (2012) Production of Eco-Friendly Bricks from Copper Mine Tailings through Geopolymerization. Construction and Building Materials, 29, 323-331. http://dx.doi.org/10.1016/j.conbuildmat.2011.10.048

[8] Stevens, A.T. (1995) Student Makes Concrete Blocks from Mine Tailings. http://www.montana.edu/cpa/news/wwwpb-archives/ag/blocks.html

[9] Jorillo Jr., P.A., et al. (2000) Study on the Utilization Technologies of Copper Mine Tailings. Unpublished Report to JSPS Core University Program. Integrated Research and Training Center, Technological University of the Philippines, Manila.

[10] Mendoza, V.A. (1999) Development of Mix Design Tables and Charts for Structural Lightweight Concrete using Indigenous Pumice Aggregates. Unpublished MSCE Thesis, Technological University of the Philippines, Manila.

[11] Metha, P.K. and Monteiro, P.J. (1993) Concrete: Structure, Properties, and Materials. 2nd Edition, Prentice Hall, Englewood Cliff.

[12] ACI 232.2R-03 (2003) Use of Fly Ash in Concrete. American Concrete Institute (ACI), Farminton Hills.

[13] Gambhir, M.L. (1986) Concrete Technology. Tata McGraw Hill, New Delhi.

[14] Neville, A.M. (1983) Properties of Concrete. 3rd Edition, Pitman Publishing Inc., Marshfield.

[15] Federal Highway Administration (1991) Standard Specifications for Construction of Roads and Bridges on Federal Highway Projects. United States Department of Transportation, Washington DC. 